\title{
A Comparative Study on the Cleaner Production Options for Fishery Wastes around Lake Tana
}

\author{
Eshetu Getahun ${ }^{1,2, a}$, Kefale Wagaw ${ }^{2, b}$ and Omprakash Sahu ${ }^{2, c^{*}}$ \\ ${ }^{1,2}$ Bahir Dar Energy Center, BiT, Bahir Dar University, Bahir Dar, Ethiopia, \\ ${ }^{2}$ Faculty of Chemical and Food Engineering, BiT, Bahir Dar University, Bahir Dar, Ethiopia \\ a Email: eshetu201384@gmail.com, b wkefale@yahoo.com, cops0121@gmail.com;
}

Keywords: Cleaner production option, Fish waste, Biodiesel, Biogas, Nutritional value

\begin{abstract}
Around Lake Tana, there are different types of fish processing cooperatives. These cooperatives simply dump the fish wastes (offal) to the Lake Tana which results environmental pollution for the marine ecosystems. In this study three cleaner production options such as biodiesel, biogas and animal feeding were investigated experimentally for the utilization of fishery wastes around Lake Tana. The study showed that fish species (labeobarbus, tilapia and catfish) wastes have oil yield of $28.65 \%, 16.35 \%$ and $5.63 \%$ and free fatty acid content of $10.5 \%, 7.5 \%$ and $6.03 \%$ respectively. In the treatment of the oil, only $3.5 \%$ of sulfuric acid was consumed to lower the FFA to the required level $(2.5 \%)$. In the biodiesel experiment, $6: 1$ ration of methanol to oil and $1 \mathrm{hr}$ of reaction retention time were found to be the optimum operating parameters. The yield of biogas was $0.016 \mathrm{ml} /$ gram of fish waste. Nutritional composition of fish wastes were $33.4 \%$ protein, $0.007 \%$ fiber, $1.26 \%$ ash, $44 \%$ moisture and $21.367 \%$ carbohydrate. The study concluded that biodiesel is the possible cleaner production option among the other for the utilization of fishery wastes around Lake Tana.
\end{abstract}

\section{Introduction}

Ethiopia is the largest livestock populations in the Africa. The livestock sector accounts for over 26 percent of agricultural GDP (2009/10) and 8 percent of export earnings [1]. Among the livestock, there are 180 different species of fish in Ethiopia and 30 of those are native to the country. The total area of the lakes and reservoirs stands at about 7000 to $8000 \mathrm{~km}^{2}$ and the important rivers stretch over $7000 \mathrm{~km}$ in the country. Fishing contribution for country's GDP is very low. Fish production potential of the country's estimated 51,000 tons per annum [1]. From these lakes, Lake Tana is the largest fresh water body situated in the north western high lands of Amhara National Regional State of Ethiopia. It serves for local transport, electric power generation, fishing, ecological restoration, recreational purposes, and dry season irrigation supply. The lake has a mean and maximum depth of $8 \mathrm{~m}$ and $14 \mathrm{~m}$, respectively. The total drainage area of the Lake Tana basin is about $16,500 \mathrm{~km}^{2}$. Currently Lake Tana is registered in UNESCO as world heritage site for its being rich in biodiversity in 2015 [2]. Fishing in Lake Tana has been started around the 18th century by the Negada Weyito Community; the other members of the communities gradually adopted the activity [3].

However, during fish processing operations, significant fish waste is generated and is currently being dumped into the lake causing environment problems like depletion of oxygen and bad odors in the lake. As the lake ecosystem is in danger it could be impossible to produce the specious of fishes in the lake due to insufficient oxygen. Fish processing by products contain fish oil, the amount of which depends upon the fat content of the specific fish species, and the distribution of fat in fish parts. After removing the flesh during fish processing operations, all other parts are considered waste which is not properly utilized. In the other way, fish and fish waste can be used to produce oil for further production of omega-3 fatty acids, and/or biodiesel. Fish oil is found in the flesh, head, frames, fin, tail, skin and guts of fish in varying quantities. These fish wastes are also used for animal feeding and/or biogas production. Generally, fish contains $2-30 \%$ fat, and about $50 \%$ of the body weight is generated as waste during the fish processing operation [4]. Therefore, 
this fish processing by-product could be a great potential source which can be used as animal feeding, sustainable energy like biogas and biodiesel production or human consumption. The main species are Nile tilapia, representing $60 \%$ of the catch, Nile perch (favoured but increasingly scarce), barbus (two species) and catfish [5].

The main aims of this study to utilize and analyzes the fish wastes as alternative energy options depending on their potential. This study focused on the comparative analysis of production of biodiesel by transestrifcation reaction, biogas production by anaerobic digestion, suability of animal feeding and human consumption by nutrient contained.

\section{Materials and Methods}

\subsection{Materials and Chemicals:}

Fishery waste was arranged from Tana Lake and washed with distilled water to remove the impurities. All chemicals methanol, potassium hydroxide, Toluene, Phenolphthalein, diethyl-ether, sulfuric acid, ethanol, and hydrochloric acid were used analytical grades.

\subsection{Experimental Setup and Descriptions:}

Preparation of Feed Stocks: Three fish species wastes such as catfish; tilapia and labeobarbus were collected from Tana Haik fish processing cooperatives. The fish wastes were washed with distilled water to separate the impurities. Then, the wastes were chopped into small size and the oils were extracted by using simple extractive boiling at a temperature of $105^{\circ} \mathrm{C}$. Finally, the oils were filtered using centrifuge and the yield was calculated. The water content, $\mathrm{pH}$, density and viscosity of the extracted oils were determined. Then, titration was conducted to determine the amount of acid value, and FFA of the resulted oils.

Biodiesel extraction: All the pretreatment and transestrification experiments were performed in a laboratory scale glass reactor, arrangement is shown in Fig. 1. The reaction flask was equipped with reflux condenser, magnetic stirrer and chiller. Hot plate magnetic stirrer was used to heat and agitate the reaction mixture. When the reaction temperature is reached $60^{\circ} \mathrm{C}$, a defined amount of catalyst previously dissolved in methanol was added to the heated oil. The mixture was stirred with magnetic stirrer for $1 \mathrm{~h}$. After cooling the reactor system, the reaction mixture was centrifuged at $4000 \mathrm{rpm}$ to separate the estrified fatty acid and alcohol- water-acid mixture. The estrified fatty acid was further heated to $103^{\circ} \mathrm{C}$ to remove any remaining water. The acid and FFA (free fatty acid) values of the fat-ester mixture were determined and recorded. After obtaining the desired FFA level, the transestrification reaction experiment was performed in the same reactor. Centrifuge was used for separation of the oils and the biodiesel from impurities. The water content, $\mathrm{pH}$, density and viscosity of the extracted oil were determined. Then, titration was conducted to determine the amount of acid value, and FFA of the resulted oil.

Sulfuric acid was used for the pretreatment of the fleshing oil as a catalyst. The esterification reaction was performed for wide range of sulfuric acid percentage concentration $(1 \%, 2 \%, 3 \%, 4 \%$, $5 \%, 6 \%, 7 \%$ and $10 \%$ ) and alcohol molar ratio of $9: 1$ so as to reduce FFA content of the fish waste oil below $2 \%$ in one hour contact time at a temperature of $65^{\circ} \mathrm{C}$. Randomized factorial design was used for the transestrification reaction. Two factors such as time and methanol oil ratio with three level was used to screen out the maximum biodiesel yield at a fixed amount of catalyst mass and temperature of $0.75 \%$ and $65^{\circ} \mathrm{C}$ respectively. The levels of methanol oil ratio were $4: 1,6: 1$ and 9:1 and the levels of time were $30 \mathrm{~min}, 60 \mathrm{~min}$ and $90 \mathrm{~min}$. After the transestrification reaction was accomplished, the glycerol phase formed in the bottom layer was removed by decantation. The biodiesel was washed with hot distilled water to decompose the soaps formed during the transesterification reaction. The biodiesel was washed with warm water and heated for about $105^{\circ} \mathrm{C}$ to separate excess methanol and water. The final product was weighed for determination of product yield and then characterized its physicochemical properties using international standards 


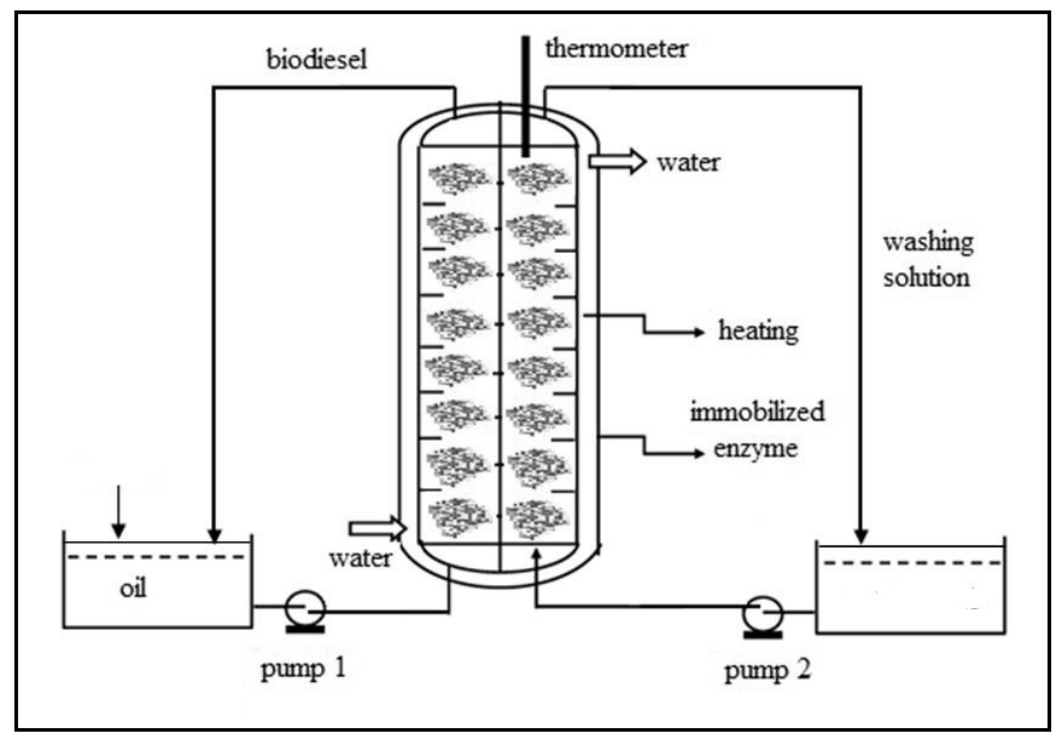

Fig.1: Experimental setup of biodiesel reactor

Biogas production: For the biogas production, temperature controlled biogas digester was used. The arrangement is shown in Fig.2. A 1:1 ratio of fish waste and water was used at a temperature of $30^{\circ} \mathrm{C}$ for digestion duration of 30 days. In two days interval the production of biogas was recorded. Along with these experiments, nutritional value of fish waste was also analyzed in order to screen out the cleaner production options of the fish wastes around Lake Tana fish processing cooperatives.

About 700 grams of fish waste was mixed with 700 grams of water and charged in to 5 liters of anaerobic digester. Then the digester was set at a temperature of $30^{\circ} \mathrm{C}$ and sealed to prevent the leakage of biogas. When the biogas started to generate, it goes to the gas collector cylinder which was fully filled with water. The water was pushed down by the gas and then daily biogas production was recorded using the water displacement method.

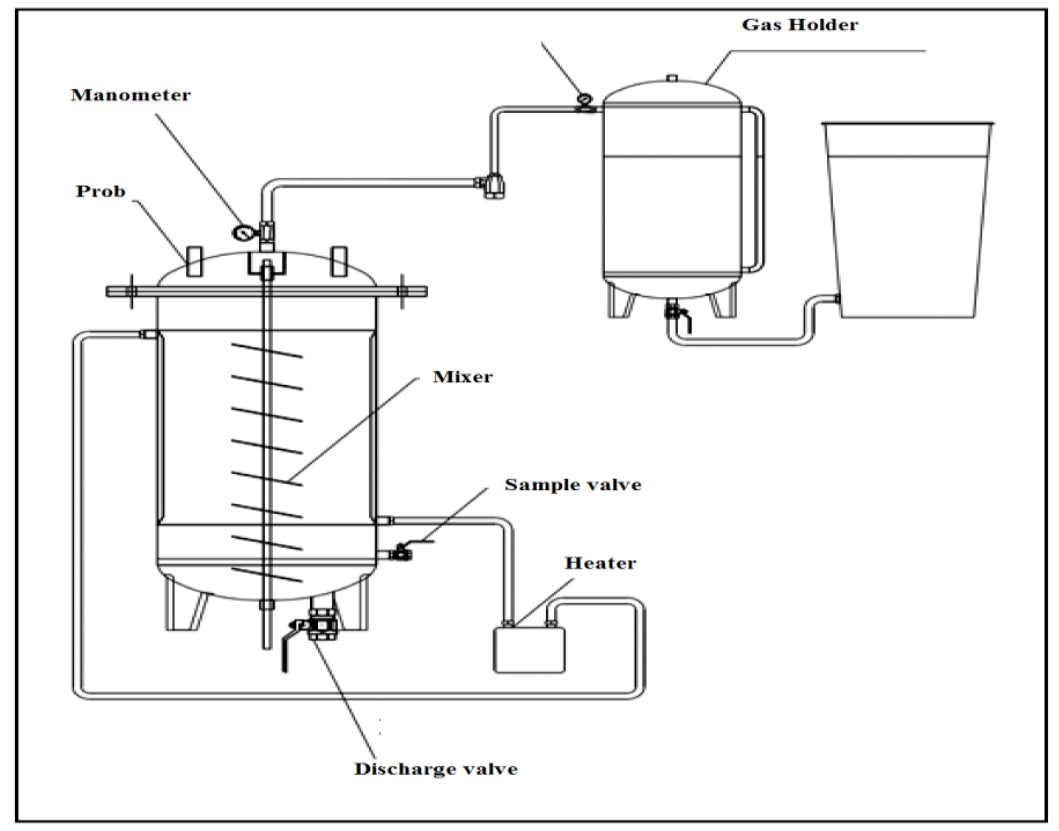

Fig.2: Experimental setup of biogas digester

Nutritional value determination: About 0.3 grames of fish wastes were mixed with $12 \mathrm{ml}$ of $0.1 \mathrm{M}$ HCL. The mixture was digested in the digester at a temperature of $400^{\circ} \mathrm{C}$ for 90 minutes to break down the bonds that hold the polypeptides together and convert them to simpler chemicals such as water, carbon dioxide, and ammonia. To this end the digested mixture was distilled to 
separate the ammonia from the digestion mixture by raising the $\mathrm{pH}$ with $44 \mathrm{ml}$ of $0.5 \mathrm{~N}$ sodium hydroxide solution, which changes the ammonium ions into ammonia gas. The ammonia was collected through boiling and distillation of the gas into a trapping solution of hydrochloric acid. Finally the trapping ammonia solution was back-titrated so that the quantity of distilled-off ammonia can be calculated and the amount of nitrogen in the protein was determined. The moisture, fiber and ash content of the fish waste were also determined to evaluate the carbohydrate component.

\subsection{Characterization}

Moisture content determination: $250 \mathrm{gm}$ of waste fish was weighed and set on into the crucible. The crucible along with the sample was placed in the oven for $4 \mathrm{hrs}$ at a temperature of $120^{\circ} \mathrm{C}$. In the interval of $4 \mathrm{hrs}$, the fish waste was taken out of the oven and in the desiccators for 3 min and the mass was recorded until the mass was kept constant. The percentage of moisture can be calculated using Eq.1.

$$
M \%=\frac{W 1-W 2}{W 1} * 100
$$

Where, W1=initial sample weight W2=final sample weight

Determination of Acid Value and FFA value: $1 \mathrm{ml}$ of oil was added to $10 \mathrm{ml}$ of diethyl ether and 23 drop of red phenophtylen was used as an indicator. The mixture was then titrated with $0.1 \mathrm{M}$ $\mathrm{KOH}$ solutions until pink color appears. The acid value was determined using Eq.2.

$$
A V=\frac{(V 1-V 2) * N * 56.1}{W}
$$

Where, $\mathrm{AV}=$ acid value, $\mathrm{V} 1=$ initial volume of $\mathrm{KOH}, \mathrm{V} 2=$ final volume of $\mathrm{KOH}, \mathrm{N}=$ normality of $\mathrm{KOH}, \mathrm{W}=$ grams of oil used, 56.1 = molecular weight of $\mathrm{KOH}$. Then, free fatty acid was determined using Eq.3.

Where, FFA= free fatty acid.

$$
F F A=\frac{A V}{2}
$$

Density (ASTM D4052-91): The biodiesel sample at a known temperature $\left(25^{\circ} \mathrm{C}\right)$ was filled into graduated cylinder $(50 \mathrm{ml})$. Hydrometer was used to measure the specific gravity of the fuels specified at $25^{\circ} \mathrm{C}$ accordingtoASTMD5002-94.Viscosity at $40^{\circ} \mathrm{C}$ (ASTM D 445): Viscometer (SV5) was used to measure the dynamic viscosity of the samples at $40^{\circ} \mathrm{C}$. The kinematic viscosity was calculated from the given data using Eq.4.

$$
\eta=\frac{\mu}{D}
$$

Where, $\eta$ is kinematic viscosity $\left(\mathrm{mm}^{2} / \mathrm{s}\right), \mu$ is dynamic viscosity (Pa.s), and $\rho$ is density $\left(\mathrm{kg} / \mathrm{m}^{3}\right)$.

Saponification Value (AOCS CD3 1993): The saponification value (SV) of the obtained biodiesel was determined via dissolving 30 gram of $\mathrm{KOH}$ pellets in one litter of ethanol to prepare $0.5 \mathrm{~N} \mathrm{KOH}$. Then, 1 gram of biodiesel sample was weighted and added into $25 \mathrm{ml} \mathrm{KOH}$ solution with $0.5 \mathrm{~N}$ molar concentration. $4 \mathrm{ml}$ of ethanol-ether solvent $(100 \mathrm{ml}$ ethanol $+100 \mathrm{ml}$ ether) was added to the mixture and then refluxed for 30 minute in a hot plate magnetic stirrer. After cooling, a few drop of phenophethaline was added and titrated by $0.5 \mathrm{~N} \mathrm{HCl}$ acid (volume Va) solution until the faint pink color permanently disappeared. And a blank determination was carried out upon the same quantity of potassium hydroxide solution at the same time and under the same conditions (volume $\mathrm{Vb}$ ). The final result was calculated using Eq.5.

$$
S V=\frac{56.1 * N *(V a-V b)}{W}
$$


Where,

$\mathrm{SV}=$ saponification value, $\mathrm{mg} \mathrm{KOH} / \mathrm{g}$

$\mathrm{W}=$ weight of oil or biodiesel $(\mathrm{g})$

$\mathrm{Va}=$ Volume $(\mathrm{ml})$ of hydrochloric acid used in test

$\mathrm{Vb}=$ Volume ( $\mathrm{ml})$ of hydrochloric acid used in blank and

$\mathrm{N}=$ Normality of hydrochloric acid.

Higher Heating value (HHV): Determination of HHV was conducted using Bomb colorimeter model IKAC 200. About $1.8 \mathrm{ml}$ of fish oil biodiesel was purred in the glass cubit. After full combustion HHV was determined.

Iodine value (IV): for calculation of the $\mathrm{HHV}(\mathrm{MJ} / \mathrm{kg})$ of oils, the empirical equation as shown in Eq.6.was suggested [6].

$$
\mathrm{HHV}=49.43-\frac{(0.041 * \mathrm{SV}+0.015 * \mathrm{IV})}{\mathrm{W}}
$$

Since the SV and HHV were experimentally determined, the IV was easily determined using this empirical equation.

Cetane Number (CN) (ASTM D613): Cetane number determination was done using empirical formula developed by kalayasiri [7]. The calculation was based on the results from Saponification number (SN) and Iodine value (IV) of oils. The CN was calculated using Eq.7.

$$
C N=46.3+\frac{5458}{S V}-0.225 * I V
$$

Biodiesel Yield: The yield of transesterification reaction was calculated using Eq.8.

$$
Y(\%)=\frac{W b}{W_{0}} * 100
$$

Where, $\mathrm{Y}=$ yield of biodiesel, $\mathrm{Wb}=$ weight of biodiesel, $\mathrm{Wo}=$ weight of oil

Biogas yield: The yield of the biogas was determined using Eq.9.

$$
Y b(\%)=\frac{W b i}{W s b} * 100
$$

Where, $\mathrm{Yb}=$ biogas yield, $\mathrm{Wbi}=$ weight of biogas, $\mathrm{Wsb}=$ weight of substrate.

Determination of nutritional value: The nitrogen content was determined using Eq.10.

$$
N c(\%)=\frac{V 1 * N * F}{W}
$$

Where, $\mathrm{Nc}=$ nitrogen content, $\mathrm{V} 1$ = volume of $\mathrm{HCl}(\mathrm{ml}), \mathrm{F}=$ correlation factor $(14), \mathrm{W}=$ sample weight (g).Then crude protein was determined using Eq.11.

$$
C p=N c * F
$$

Where, $\mathrm{Cp}=$ crude protein (\%). The fiber content was also determined using Eq.12.

$$
C f=W r+W p-W b r-\left(\frac{W a}{W s}\right) * 100
$$

Where, $\mathrm{Wr}+\mathrm{Wp}=1.48565 \mathrm{gram}, \mathrm{Wbr}=1.349$ gram, $\mathrm{Wa}=0.0156$ gram and $\mathrm{Ws}=12$ gram.

Finally the carbohydrate was determined from the total composition of the sample (moisture, fiber, protein, ash and carbohydrate). 


\section{Results and Discussions}

\subsection{Fish Waste Oil Extraction and Characterization:}

Different experimental analysis was conducted on each fish species oil extraction and the physicochemical properties of the extracted oils were shown in Table 1.

Table 1: Physicochemical properties of three species fish waste oils

\begin{tabular}{lcccccc}
\hline Fish species & $\begin{array}{c}\text { Density } \\
{[\mathrm{g} / \mathrm{ml}]}\end{array}$ & $\begin{array}{c}\text { Kinematic } \\
\text { Viscosity } \\
{[\mathrm{mm} 2 / \mathrm{s}] @ 40^{\circ} \mathrm{C}}\end{array}$ & $\begin{array}{c}\mathrm{AV} \\
{[\mathrm{mgKOH}]}\end{array}$ & $\begin{array}{c}\text { FFA } \\
{[\mathrm{mg} \mathrm{KOH}]}\end{array}$ & $\begin{array}{c}\text { Moisture } \\
\text { Content } \\
(\%)\end{array}$ & $\begin{array}{c}\text { Oil yield } \\
(\%)\end{array}$ \\
\hline Labeobarbus & 0.901 & 23 & 21.11 & 10.5 & 52 & 28.65 \\
Catfish & 0.91 & 25 & 12.06 & 6.03 & 35 & 5.63 \\
Tilapia & 0.9 & 18 & 15.08 & 7.5 & 45 & 16.35 \\
\hline
\end{tabular}

The results show that the percentage moisture content of species labeobarbus, tilapia and catfish were $52 \%, 45 \%$ and $35 \%$, respectively. This signifies that species labeobarbus will require higher drying time than species tilapia when subjected to the same drying condition. However, species catfish has the least moisture content. While their oil contents were $28.65 \%, 16.35 \%$ and $5.63 \%$, signifying that species labeobarbus has a higher amount of oil while catfish has the least amount of oil extracted. From the same result, it can be concluding that moisture content of the fishes is a reflection of their oil content. It might be due to species with higher moisture content yield high amount of oil when extracted; this can be easily observed in Fig.3 that the color of fish waste oil was deep red. It was also observed that species labeobarbus has higher FFA than species tilapia. However species catfish has least FFA contents. It was reported in different studies that pretreatment is mandatory when FFA of the oil is above $2.5 \%$ [6]. Due to high level of FFA enhances the saponification reaction by depressing the biodiesel reaction route.

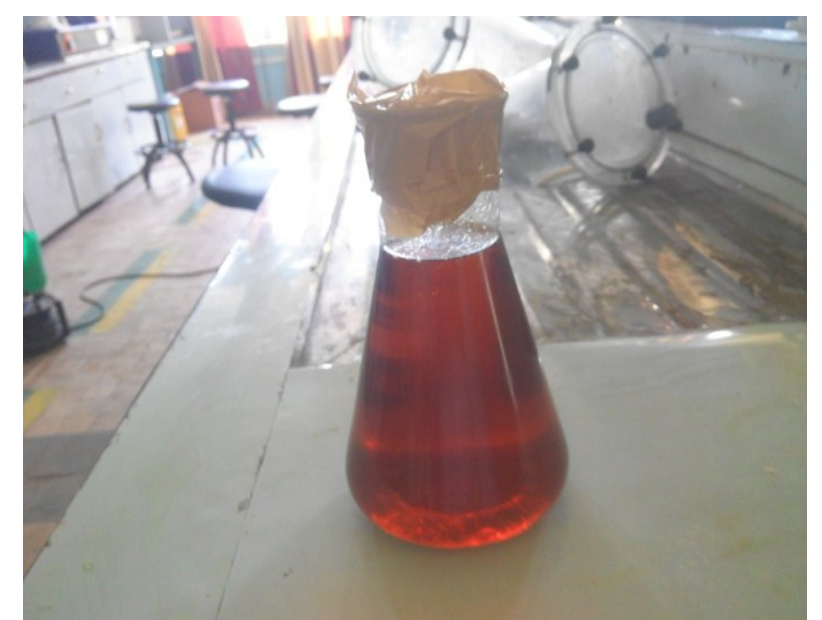

Fig.3: Extracted fish waste oil

\subsection{Fish waste oil treatment and Transestrification:}

The transestrification has been carried out with treated fish oil. Since each fish species has considerable amount of FFA content, the pretreatment reaction was mandatory. One of the pretreatment mechanisms to reduce FFA content is estrification reaction. In this study Labeobarbus has significant yield of oil for the production of biodiesel. However it has also considerable amount of FFA which needs estrification reaction. The esterification reaction was conducted at $65^{\circ} \mathrm{C}$ for $1 \mathrm{hr}$ retention time. Sulfuric acid was used to initiate the esterification reaction. The result is presented in Fig.4. It can be seen that the acid values of the fish waste oils were decreased with increasing the amount of sulfuric acid. The FFA value was determined as half of the acid value of the fish waste oils. It was also observed that only $3.5 \%$ of sulfuric acid is needed to lower the FFA to the required level (2.5\%). 


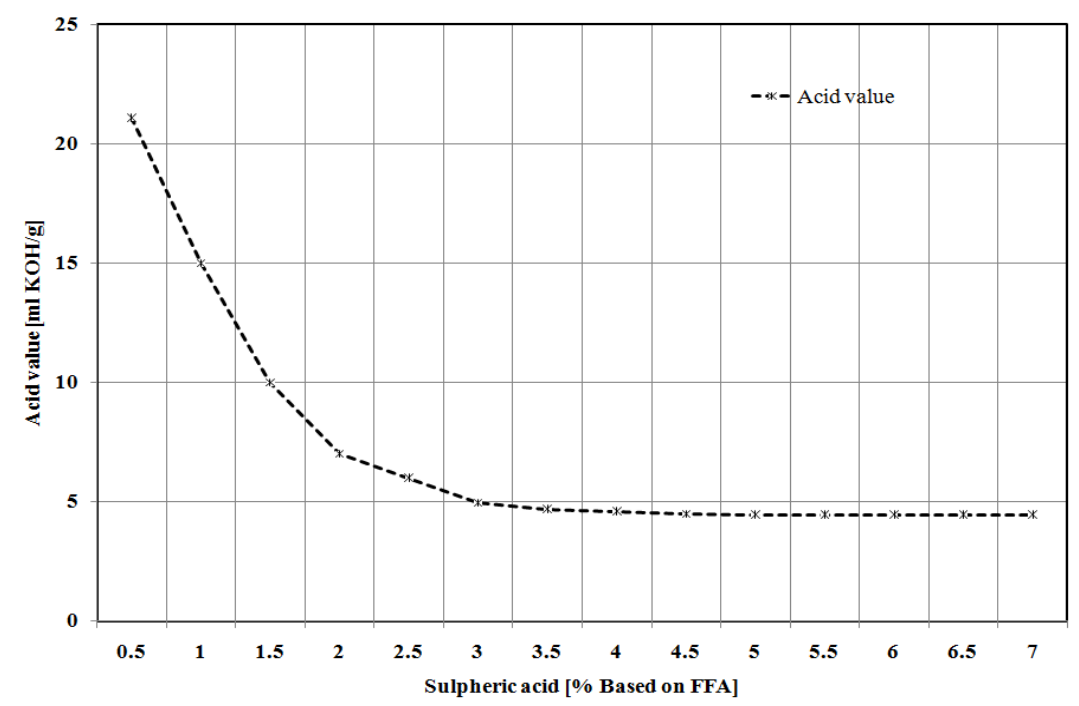

Fig.4: Effect of catalyst on the acid value of pretreated fish waste oil

To this end transestrification reaction was commenced using estrified labeobarbus oil. As it can be seen in Fig.5, biodiesel and glycerol was form two distinct layers where the upper part was biodiesel and the bottom layer was the glycerol.

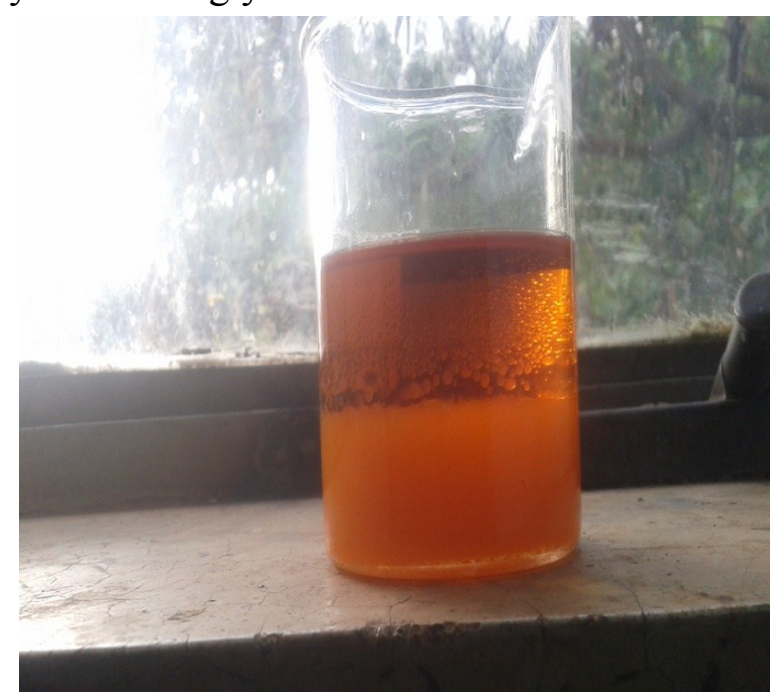

Fig.5: Transestrification reaction and biodiesel layer

The fish waste biodiesel was separated first by decantation and then by centrifuge finally purified by washing several times with warm water. The impurities such as trace amount of soap and glycerol were settled down during washing as shown in Fig.6. The calculated yield and the physicochemical properties of fish waste biodiesel were displayed in Table 2.

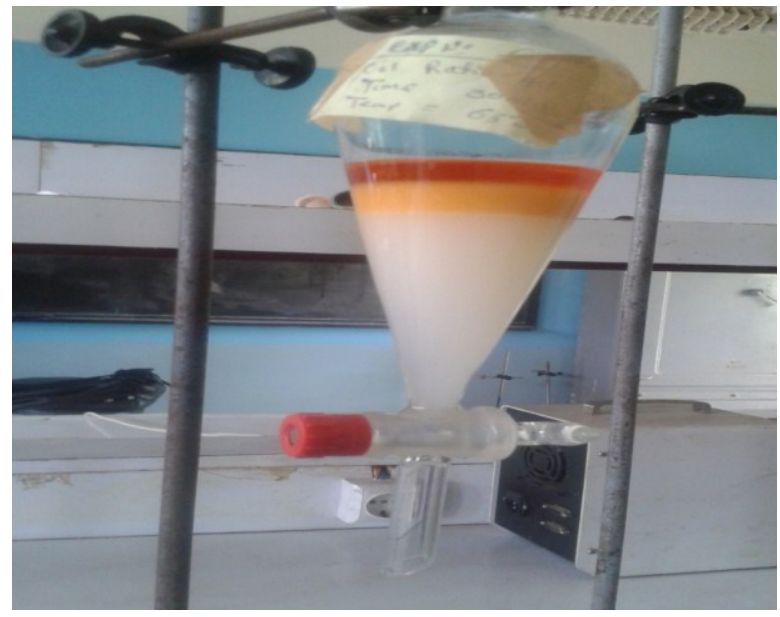

Fig.6: Washing of biodiesel 
Effect of reaction time on biodiesel yield: The yield of biodiesel was determined at moderate operating condition of the reaction. The fish waste oil biodiesel yield is presented as function of reaction retention time with different oil to methanol ratio such as 4:1, 6:1 and 9:1. As it can be seen in Fig.7 reaction is strongly dependent on reaction time. In the beginning, the reaction was slow due to the mixing and the dispersion of methanol into oil, and the biodiesel yield increases very quickly in the reaction time range from 30 to $60 \mathrm{~min}$. Moreover, as it can be observed that excessive reaction time leads to a bit reduction in the product yield due to the backward reaction, resulting in a loss of esters as well as causing more fatty acids to form soaps. Therefore, the optimum reaction time is 60 minute for all methanol oil ratios. It can be also observed that in Fig. 7 the biodiesel yield increases as the molar ratio increases from 4:1 to 6:1. However, beyond the molar ratio of 6:1 the excessively added methanol has no significant effect on the production yield. Rather it makes more difficult the separation of glycerol as shown in Fig.8 and thus decreasing the biodiesel yield. It has also mentioned elsewhere that biodiesel yield increases to some extent of methanol oil molar ratio and then declined [8].

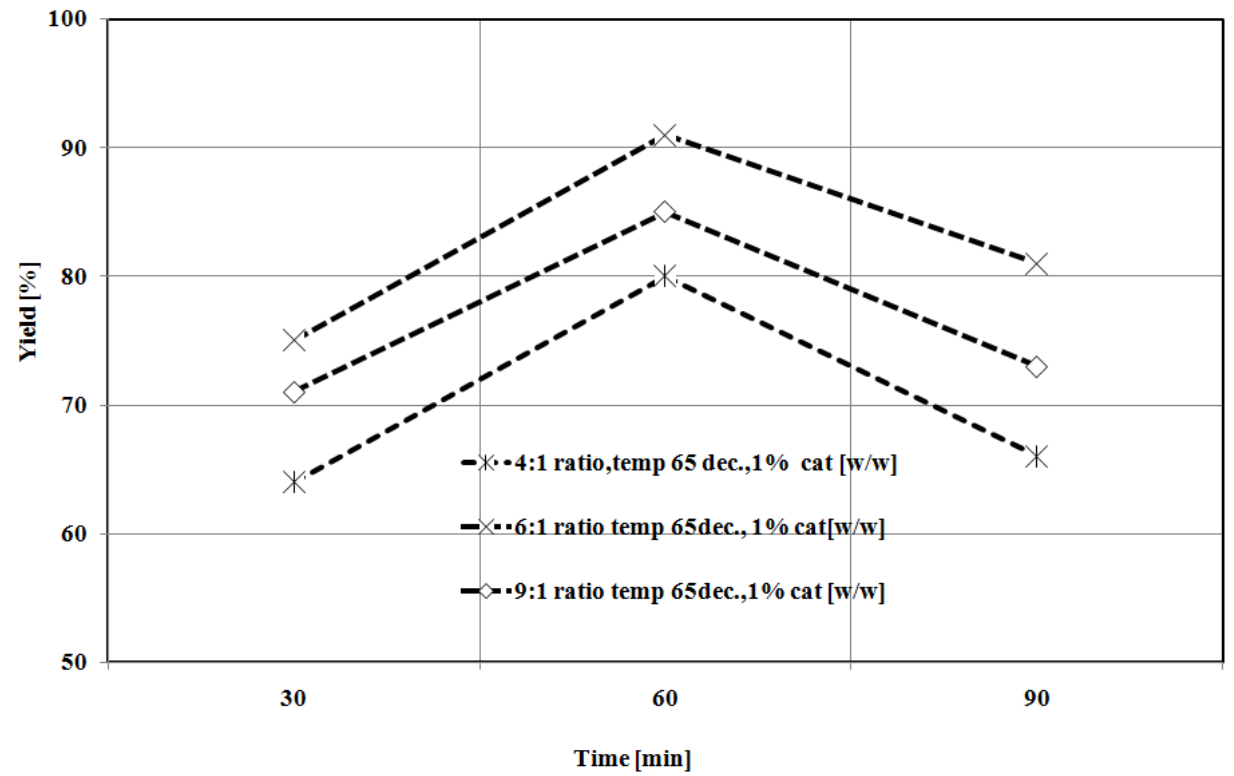

Fig. 7: Effect of retention time on biodiesel yield

Table 2: Fuel properties of biodiesel at different operating conditions

\begin{tabular}{cccccccccc}
\hline Run & $\begin{array}{c}\text { Methanol } \\
\text { to oil ratio }\end{array}$ & Time & $\begin{array}{c}\text { Density } \\
{[\mathrm{g} / \mathrm{ml}]}\end{array}$ & $\begin{array}{c}\text { Kinematic } \\
\text { Viscosity } \\
{[\mathrm{mm} 2 / \mathrm{s}]}\end{array}$ & $\begin{array}{c}\mathrm{SV} \\
{[\mathrm{mgKOH} / \mathrm{g}]}\end{array}$ & $\begin{array}{c}\mathrm{HHV} \\
{[\mathrm{kJ} / \mathrm{kg}]}\end{array}$ & $\begin{array}{l}\text { IV[gI2/100ml }] \\
\text { Yield } \\
{[\%]}\end{array}$ & $\mathrm{CN}$ \\
\hline 1 & $4: 1$ & 30 & 0.885 & 2.3 & 148.7 & 276.19 & 155.24 & 64 & 48.08 \\
2 & $4: 1$ & 60 & 0.911 & 3.0 & 140.275 & 283.20 & 159.68 & 79 & 49.28 \\
3 & $4: 1$ & 90 & 0.912 & 2.5 & 149.6 & 373.33 & 220.02 & 66 & 33.28 \\
4 & $6: 1$ & 30 & 0.890 & 5.0 & 148.6 & 262.50 & 146.11 & 75 & 50.16 \\
5 & $6: 1$ & 60 & 0.877 & 3.3 & 144.32 & 121.74 & 52.15 & 91 & 72.38 \\
6 & $6: 1$ & 90 & 0.909 & 4.0 & 156.3 & 295.24 & 168.15 & 81 & 43.39 \\
7 & $9: 1$ & 30 & 0.919 & 4.5 & 158.65 & 290.14 & 164.81 & 71 & 43.62 \\
8 & $9: 1$ & 60 & 0.892 & 2.6 & 112.22 & 290.91 & 164.05 & 85 & 58.02 \\
9 & $9: 1$ & 90 & 0.901 & 2.8 & 134.664 & 83.52 & 26.41 & 73 & 80.89
\end{tabular}

Note: Based on this, the optimum molar ratio of methanol to oil is $6: 1$. 


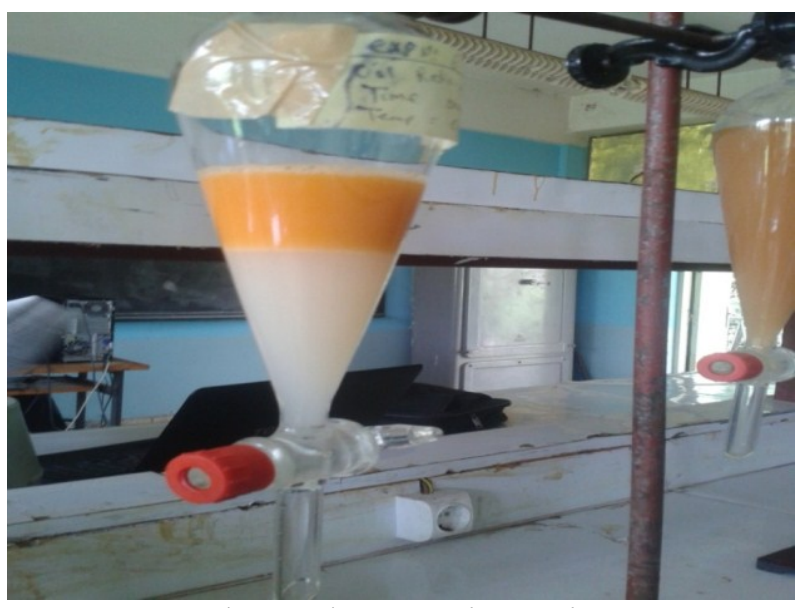

Fig.8: Glycerol separation using water

\subsection{Physicochemical Characteristics of Fish Waste Biodiesel:}

The iodine value (IV) or iodine number was introduced in biodiesel quality standards for evaluating their stability to oxidation. The IV is a measurement of total unsaturation of fatty acids measured in $\mathrm{g}$ iodine $/ 100 \mathrm{~g}$ of biodiesel sample, when formally adding iodine to the double bonds [10,11]. As it can be seen in Table 2 the iodine value of the produced biodiesel was in the range of 26.4-220gram of $\mathrm{I}_{2} / 100 \mathrm{ml}$ of oil. As it has been mentioned (Table 2) at the optimum operating condition (6:1 methanol to oil ratio and $60^{\circ} \mathrm{C}$ ) the iodine number was 52.2 . Biodiesel with high IV is easily oxidized in contact with air. Different researchers reported that the iodine value highly depends on the nature and ester composition of the feed stocks used in biodiesel production. Therefore the IV is limited in various regions of the world depending on the specific conditions: 120 in Europe and Japan, 130 in Europe for biodiesel as heating oil, 140 in South Africa, in Brazil it is not limited and in the U.S., Australia and India it is not included in the quality standard (it would exclude feed stocks like sunflower and soybean oil) [11]. Biodiesel with high IV tends to polymerize and form deposits on injector nozzles, piston rings and piston ring grooves. The tendency of polymerization increases with the degree of unsaturation of the fatty acids $[11,12]$. This suggests that the quality of biodiesel produced in this work was in good agreement with the other literature results. The density of biodiesel was determined via hydrometer. It was observed in this study that the density of biodiesel decreased from 909 to $877 \mathrm{Kg} / \mathrm{m}^{3}$ through transestrification reaction.

Cetane number $(\mathrm{CN})$ is a dimensionless indicator that characterizes ignition quality of fuels for compression ignition engines (CIE). Since in the CIE burning of the fuel-air mixture is initiated by compression ignition of the fuel, the cetane number is a primary indicator of fuel quality as it describes the ease of its self-ignition. As it can be seen in Table 2, CN was found in the range of 33 -80. Researchers reported that the appropriate $\mathrm{CN}$ is in the range of 15-100 [11]. So it is important to conclude that the $\mathrm{CN}$ investigated in this study was in a good agreement with literature results. The viscosity of liquid fuels is their property to resist the relative movement tendency of their composing layers due to intermolecular attraction forces. Viscosity influences the ease of starting the engine, the spray quality, the size of the particles (drops), the penetration of the injected jet and the quality of the fuel-air mixture combustion [13]. The viscosity of this study is presented in Table2.

\subsection{Biogas Production:}

The biogas production was carried out with three different types of fish waste. The fish waste sludge was prepared by mixing fish wastes with water and the biogas production capacity was recorded in two days interval. As it can be seen in Fig.9 the generation of biogas was to somewhat up and down. Different researchers indicate that after gas production, $\mathrm{pH}$ is the best indicator of future digester instability [9]. 


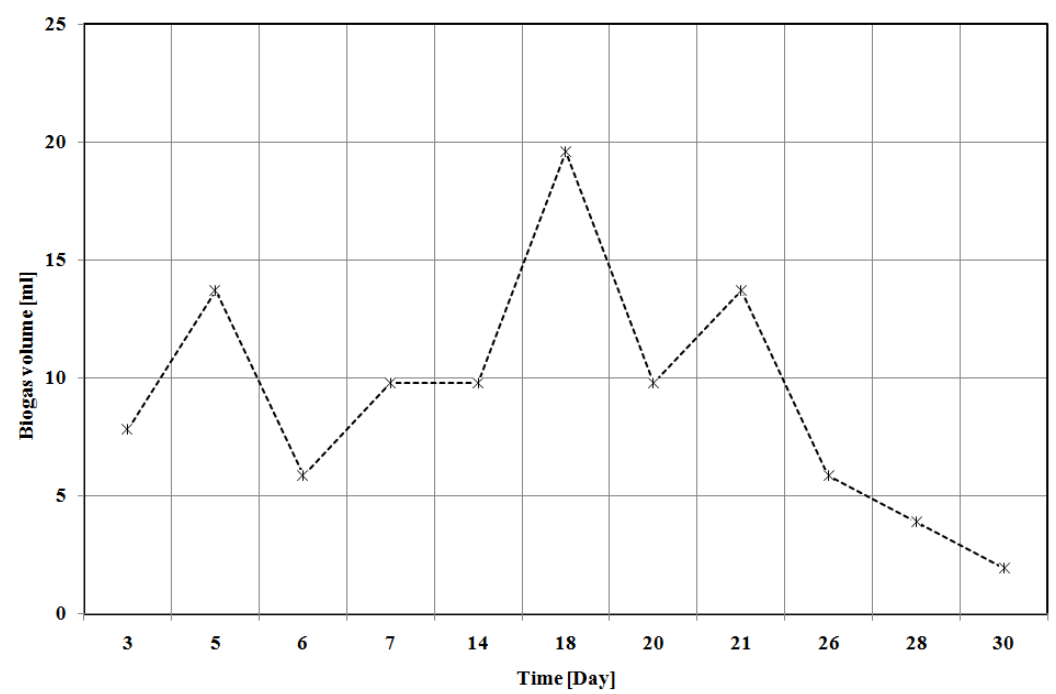

Fig. 9: Biogas production

Initially, $\mathrm{pH}$ was decrease as organic matter undergoes acetogenesis, but methanogens rapidly consume those acids increasing $\mathrm{pH}$ and stabilizing digester performance. The maximum biogas generations were obtained at $16^{\text {th }}$ day after the biogas started to generate. From this study it was found that the total generation of the biogas was $0.016 \mathrm{ml} / \mathrm{gram}$ of fish waste.

\subsection{Nutritional value determination:}

The nutritional value of fish wastes is presented in Fig.10. The study shows that the composition of fish waste protein, fiber, ash, moisture content and carbohydrate content were $33.367 \%, 0.0067 \%$, $1.26 \%, 44 \%$ and $21.367 \%$ respectively. It can be seen that the major composition of fish waste was moisture content, crude protein and carbohydrate. However, the fish wastes have the least fiber and ash content values. Different researchers reported that fish wastes have different nutritional values depending on the types of fish species and geographical location [10]. Therefore, the finding of this study was in a good agreement with the literature values and it is difficult to conclude that the fish wastes are used for human feeding at the current production quality.

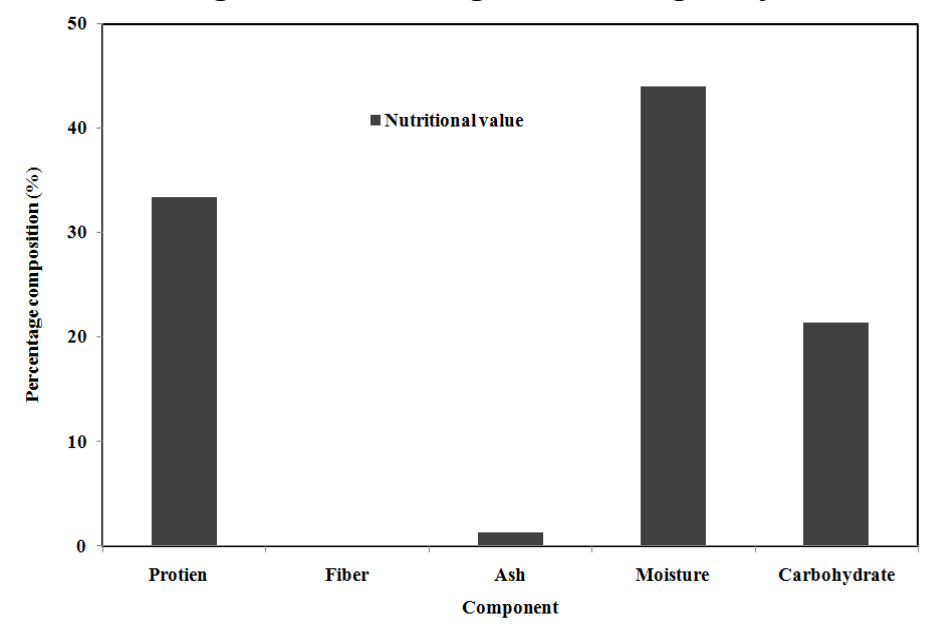

Fig. 10: Nutritional values of fish wastes

\section{Conclusions}

It is concluding that three fish species wastes were selected for their potential of oil production and investigated experimentally for biodiesel production, biogas production and nutritional value determination. The result of biodiesel was characterized for its physicochemical properties. The study shows that fish species (labeobarbus, tilapia and catfish) wastes have oil yield of 28.65, 16.35 and $5.63 \%$, respectively signifying that species labeobarbus has a higher amount of oil while catfish has the least amount of oil extracted. Based on species oil content, labeobarbus species was 
favorable to produce biodiesel. The fish species (labeobarbus, tilapia and catfish) wastes have FFA content of $10.5,7.5$ and $6.03 \%$. Consequently, acid pretreatment experiment was conducted to reduce the FFA below $2.5 \%$ so as to minimize the saponification reaction. From the study, it was observed that methanol ratio of $6: 1$, sulfuric acid percentage of $3.5 \%(\mathrm{w} / \mathrm{w})$ and contact time of $1 \mathrm{hr}$ were sufficient to reduce FFA to $2.5 \%$ at $65^{\circ} \mathrm{C}$. The proximate transestrification reaction yield is $91 \%$ at optimum operating conditions. And also from the physicochemical property analysis, the produced biodiesel have a viscosity of $804.6 \mathrm{pa} . \mathrm{s}$, HHV of $121.74 \mathrm{~kJ} / \mathrm{kg}$, iodine value of $52.2 \mathrm{gI} 2 / 100 \mathrm{ml}$ and density of $877.1 \mathrm{Kg} / \mathrm{m}^{3}$ which were in the range of international standards. For production of biogas an anaerobic digester was used and the yield was determined using water displacement method. The results show the production of biogas was $0.016 \mathrm{ml} / \mathrm{gram}$ of fish waste. From the nutritional analysis it was observed that fish wastes have the composition of protein, fiber, ash, moisture and carbohydrate content were $33.367 \%, 0.00665 \%, 1.26 \%, 44 \%$ and $21.367 \%$ respectively. Therefore, based on the comparative analysis and current energy demand, accessibility and oil potential, biodiesel production from fish wastes was taking the lion share of the cleaner production options for the utilization of fish wastes around Lake Tana.

\section{Acknowledgement}

The research fund was granted from the research and post graduate office of Bahir Dar Institute of technology, Bahir Dar University.

\section{References}

[1] Assefa Mitike Janko, Fish Production, Consumption and Management in Ethiopia, Research Journal of Agriculture and Environmental Management. 3(9) (2014) 460-466.

[2] Information on Ministry of Science and Technology, http/www.most.gov.et.

[3] Yalew, Alayu, et al, Adaptation and growth performance of nile tilapia (oreochromis niloticus) in integrated fish farming on north western Amhara region, The Ethiopian fisheries and aquatic sciences association (EFASA), 2009.

[4] Dave, Deepika, et al, Marine Oils as Potential Feedstock for Biodiesel Production: Physicochemical Characterization, Journal of Bioprocessing \& Biotechniques (2014).

[5] D. Reyntjens, T. Wudneh, Fisheries development in Ethiopia, Project News, Bulletin. 11:1 (1998).

[6] Eshetu Getahun, Nigus Gabiyye, Experimental Investigation and Characterization of Biodiesel Production from Leather Industry Fleshing Wastes, International Journal of Renewable and Sustainable Energy. 2:3 (2013) 120-129. doi: 10.11648/j.ijrse.20130203.17

[7] Roces, Susan A., et al, Methanolysis of Jatropha oil using conventional heating, ASEAN Journal of Chemical Engineering Research. 11:1 (2011).

[8] Kang Liu, Rui Wang. Biodiesel Production By Transesterification Of Duck Oil With Methanol In The Presence Of Alkali Catalyst, Petroleum \& Coal. 55:1 (2013) 68-72.

[9] M. Poliafico, Anaerobic digestion: decision support software, Master's thesis, Department of civil, structural and environmental engineering, Cork institute of technology, Cork, Ireland, 2007.

[10] V.V. Ramakrishnan, et al, Extraction of oil from mackerel fish processing waste using Alcalase enzyme, Enzyme Engineering. (2013).

[11]Barabás, István, Ioan-Adrian Todoruţ, Biodiesel quality, standards and properties, BiodieselQuality, Emissions and By-Products. (2011) 3-28.

[12] American Society for Testing and Materials (ASTM). "ASTM D6751-09, Standard Specification for Biodiesel Fuel Blend Stock (B100) for Middle Distillate Fuels." West Conshohocken, PA: ASTM, 2009.

[13]NREL, Biodiesel Handling and User Guide, Fourth Edition, 2009. 